\title{
ANALYSIS OF WIND INFLUENCE TO STATIC STABILITY OF THE EAVE FRAMEWORK
}

\author{
Darko Damjanović, Dražan Kozak, Mario Holik
}

Original scientific paper Eave framework is analyzed in this paper from the standpoint of statics. Loads taken into account are self-weight, snow weight and wind influence. 3D model of eave framework is generated in the software PartSolution (Cadenas) with certain simplifications in geometry. Simplifications are taken into account in order to reduce costs of the numerical calculation, especially the FSI calculation. The resulting pressure distribution solution obtained from CFD calculation is set as the boundary conditions on the eave framework when performing structural analysis. Solutions for equivalent stress as well as deformation are presented and analyzed. Also, solutions for airflow prediction around the eave framework are presented in order to analyze if it is possible to perform some changes in the construction in terms of reducing the air resistance and thus reducing the wind load on the construction.

Keywords: CFD; Computational Fluid Dynamics; eave framework; FSI; Fluid-Structure Interaction; wind influence

\section{Analiza utjecaja vjetra na statičku stabilnost konstrukcije nadstrešnice}

Izvorni znanstveni članak

U članku je analizirana noseća konstrukcija nadstrešnice u statičkom smislu. Opterećenja uzeta u obzir su vlastita težina konstrukcije nadstrešnice, težina snijega te utjecaj vjetra. 3D model konstrukcije nadstrešnice generiran je u softveru PartSolution (Cadenas) s određenim pojednostavljenjima geometrije. Pojednostavljenja geometrije uzeta su u obzir s ciljem pojednostavljenja numeričkog modela, posebice prilikom provođenja FSI simlacije. Rezultirajuća raspodjela tlakova na geometriju konstrukcije nadstrešnice dobivena CFD simulacijom postavljena je kao ulazni rubni uvijet prilikom provođenja statičke simulacije provjere čvrstoće. Prikazana su i analizirana rješenja za ekvivalentna naprezanja te za deformacije. Nadalje, prikazana su također rješenja za tok zraka oko konstrukcije nadstrešnice u smislu analiziranja mogućih promjena geometrije u smislu smanjenja otpora zraka a samim time i smanjenja opterećenja od vjetra na konstrukciju nadstrešnice.

Ključne riječi: CFD; FSI; interakcija fluid - kruto tijelo; konstrukcija nadstrešnice; računalna dinamika fluida; utjecaj vjetra

\section{Introduction}

Free standing eave frameworks serve as protection from the sun, rain, snow and other weather conditions. One of the most important loads, in addition to its own weight is a load of snow and wind. In most cases eave framework construction is made from steel while the tent is made from $100 \%$ polyacrylic whose characteristics are high strength, waterproof and antistatic to dust and atmospheric pollution. Some construction variation of eave framework can be seen in [1].

Geographic location of considered eave framework is Brod - Posavina County and the main purpose of considered eave framework is to protect people from atmospheric influences like sun, wind and rain. The FSI calculation takes into account wind influence as the real one, i.e. as it happens in nature, more or less. So it represents more real calculation than calculation using some analytical approach. Some good applications of FSI to obtain loading of wind to the structure and calculate strength can be seen in $[2,3]$.

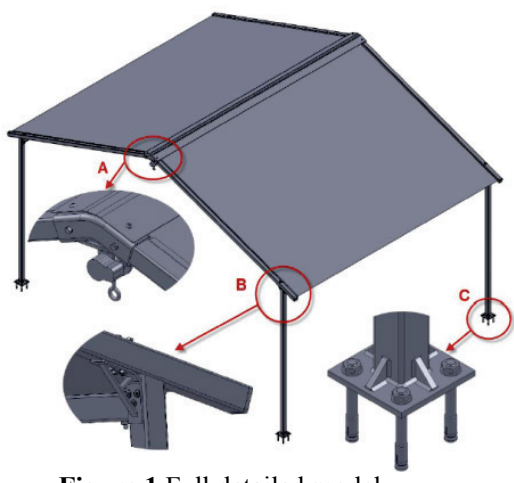

Figure 1 Full detailed model

\section{Geometry}

The eave framework model is generated using PartSolution (Cadenas) software. The model is modeled in full details (Fig. 1) including welds, screws, reinforcements etc., while simplified model is used to make finite element and CFD calculations (Fig. 2). Basic dimensions of the construction are shown in Fig. 3. From static point of view this is really a simple model to solve, but it is quite hard to take into account wind influence, so the Fluid - Structure Interaction method was used to analyze wind influence on the eave framework.

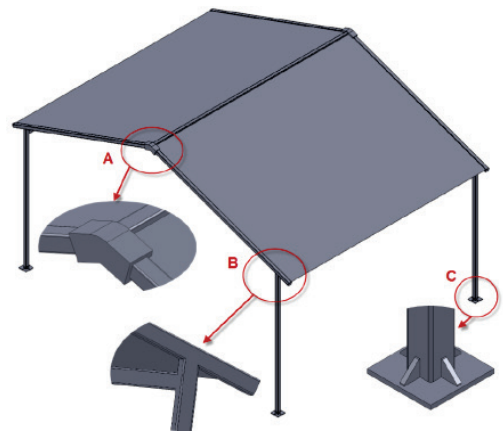

Figure 2 Simplified model for numerical calculations
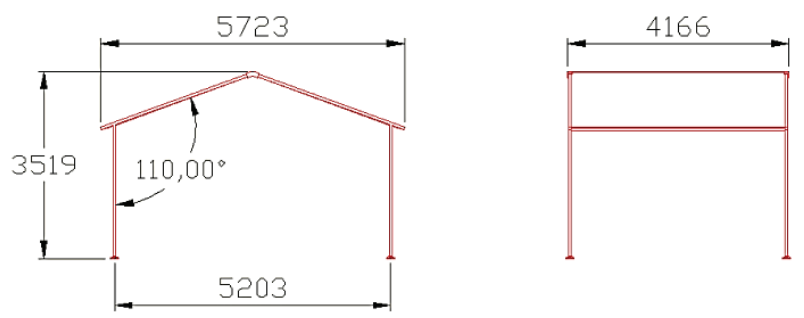

Figure 3 Basic dimensions of the construction 


\section{Load conditions}

As mentioned earlier, besides self-weight it is needed to include loads from snow and wind as the most dominant regarding the structural stability. Snow loading can be calculated using (1):

$$
s=s_{k} \cdot \mu_{i} \cdot C_{e} \cdot C_{t}
$$

where:

$s_{\mathrm{k}} \quad$ - characteristic snow load on the ground, (according to Tab. 1 for altitude and Fig. 4 for geographic location),

$\mu_{\mathrm{i}} \quad$ - shape coefficient (depending on the type and slope of the roof), Tab. 2,

$C_{\mathrm{e}} \quad$ - exposure coefficient which takes into account hard conditions of wind blowing (in most cases $C_{\mathrm{e}}=1$,

$C_{\mathrm{t}}$ - temperature coefficient which takes into account thermal insulation of the roof (in most cases $C_{\mathrm{t}}=1$.

Table 1 Characteristic snow load on the ground

\begin{tabular}{|c|c|c|c|c|}
\hline \multirow{2}{*}{ Altitude } & \multicolumn{4}{|c|}{$s_{\mathrm{k}}, \mathrm{kN} / \mathrm{m}^{2}$} \\
\cline { 2 - 5 } & I & II & III & IV \\
\hline 0 & 0,88 & 0,75 & 0,14 & 0,18 \\
\hline 100 & 1,09 & 1,05 & 0,45 & 0,33 \\
\hline 200 & 1,31 & 1,38 & 0,80 & 0,50 \\
\hline 300 & 1,55 & 1,76 & 1,20 & 0,70 \\
\hline 400 & 1,80 & 2,18 & 1,65 & 0,92 \\
\hline 500 & 2,06 & 2,63 & 2,15 & 1,16 \\
\hline$\ldots$ & $\ldots$ & $\ldots$ & $\ldots$ & $\ldots$ \\
\hline
\end{tabular}

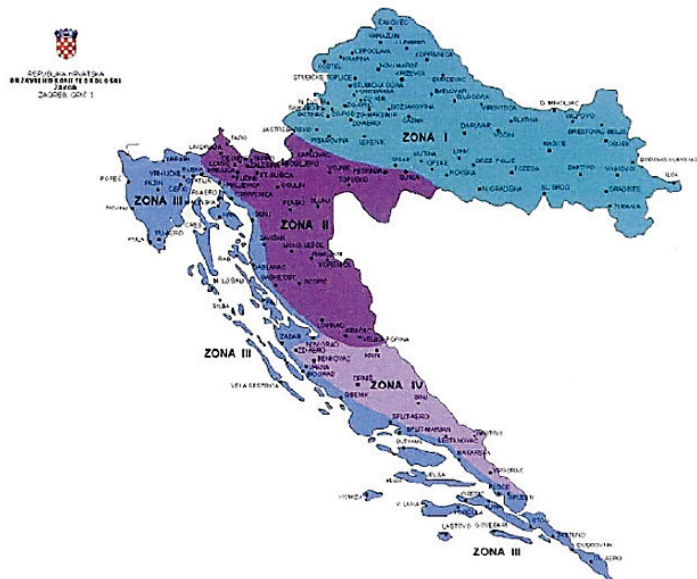

Figure 4 Geographic location for characteristic snow load in Croatia [4]

Table 2 Shape coefficient

\begin{tabular}{|c|c|c|c|}
\hline $\begin{array}{c}\text { Slope of the } \\
\text { roof }\end{array}$ & $0^{\circ}<\alpha \leq 30^{\circ}$ & $30^{\circ}<\alpha<60^{\circ}$ & $\alpha \geq 60^{\circ}$ \\
\hline $\begin{array}{c}\text { Shape } \\
\text { coefficient } \mu_{1}\end{array}$ & 0,8 & $0,8(60-\alpha) / 30$ & 0 \\
\hline $\begin{array}{c}\text { Shape } \\
\text { coefficient } \mu_{2}\end{array}$ & $0,8+0,8 \alpha / 30$ & 1,6 & - \\
\hline
\end{tabular}

So according to the presented tables and figures and taking into account geographic location of the eave framework, coefficients for this particular case are:

$s_{\mathrm{k}}=1,09 \mathrm{kN} / \mathrm{m}^{2}$

$\mu_{\mathrm{i}}=0,8$
$C_{\mathrm{e}}=1$

$C_{\mathrm{t}}=1$

And finally, snow load on the roof is:

$S=0,872 \mathrm{kN} / \mathrm{m}^{2}$

Wind loading is considered like quasi-static pressure acting perpendicular to the surface of the building. Besides that, there are special cases as tangential friction forces which are the result of wind blowing across long and flat surfaces. Characteristic pressure of wind is pressure of basic speed of the wind derived from basic fundamental value of wind speed [5]. Basic wind speed is

$v_{\mathrm{b}}=c_{\mathrm{dir}} \cdot c_{\text {season }} \cdot v_{\mathrm{b}, 0}$

where:

$v_{\mathrm{b}} \quad$ - pressure of basic speed of the wind,

$c_{\mathrm{dir}} \quad-$ wind direction coefficient,

$c_{\text {season }}$ - season coefficient,

$v_{\mathrm{b}, 0} \quad$ - fundamental value of basic speed of the wind, Fig. 5.

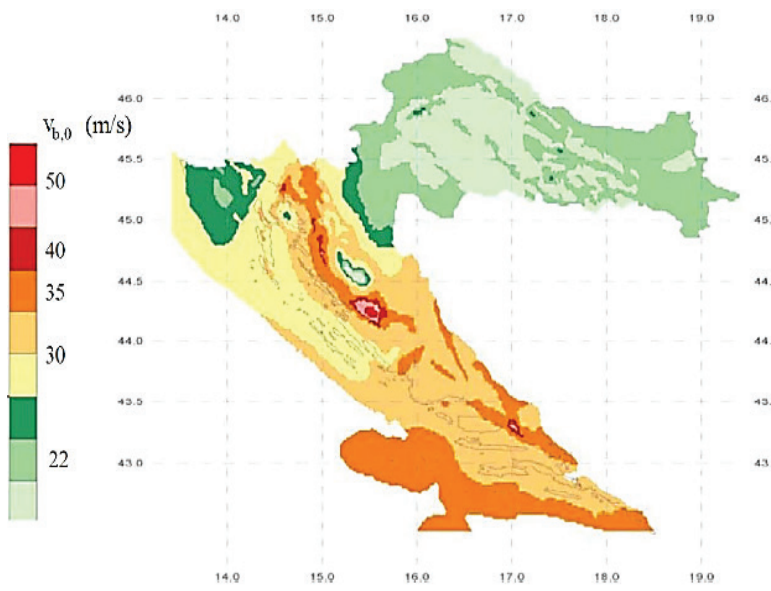

Figure 5 Fundamental value of basic speed of the wind [5]

If not otherwise specified, coefficients $c_{\text {dir }}$ and $c_{\text {season }}$ are taken with value 1 [5]. In that case $v_{\mathrm{b}}=v_{\mathrm{b}, 0}$, and according to Fig. $4, v_{\mathrm{b}, 0}=25 \mathrm{~m} / \mathrm{s}$. That speed is input value for further Fluid - Structure Interaction simulation.

\section{Computational fluid dynamics}

The air flow around the eave framework was investigated by computational fluid dynamics (CFD) simulations based on a steady Reynolds averaged Navier Stokes equations (RANS) model. Simulations were performed by ANSYS CFX software based on a finite volume approach [6].

The standard $k-\varepsilon$ turbulence model is used. All of the transport equations were discretized using first order upwind scheme. The SIMPLE algorithm is used for pressure velocity coupling.

\subsection{Governing equations}

The equations that govern the fluid flow around the eave framework are the time-averaged continuity and 
momentum equations which, for the steady flow of a constant property fluid, are given by [7]

$$
\begin{aligned}
& \frac{\partial \bar{v}_{j}}{\partial x_{j}}=0 \\
& \frac{\partial\left(\rho \bar{v}_{j} \bar{v}_{i}\right)}{\partial x_{j}}=-\frac{\partial \bar{p}}{\partial x_{i}}+\frac{\partial}{\partial x_{i}}\left[\left(\mu+\mu_{\mathrm{t}}\right) \cdot\left(\frac{\partial \bar{v}_{i}}{\partial x_{j}}+\frac{\partial \bar{v}_{j}}{\partial x_{i}}\right)\right]
\end{aligned}
$$

where:

$\bar{v}_{j}$ - mean velocity vector,

$\bar{p}$ - effective pressure,

$\mu_{\mathrm{t}}$ - coefficient of turbulent viscosity.

Coefficient of turbulent viscosity is defined as [7]

$\mu_{\mathrm{t}}=C_{\mu} \rho \frac{\bar{k}^{2}}{\bar{\varepsilon}}$

It is supposed as fully developed turbulent flow and high value of turbulent Reynolds number. Equation for turbulent kinetic energy is [7]

$$
\frac{\partial}{\partial x_{\mathrm{j}}}\left(\rho \bar{v}_{j} \bar{k}\right)=\frac{\partial}{\partial x_{\mathrm{j}}}\left[\left(\mu+\frac{\mu_{\mathrm{t}}}{\sigma^{k}}\right) \frac{\partial \bar{k}}{\partial x_{\mathrm{j}}}\right]+G-\rho \bar{\varepsilon}
$$

where $\mathrm{G}$ is generation of turbulent kinetic energy defined as [7]

$$
G=\mu_{\mathrm{t}}\left(\frac{\partial \bar{v}_{i}}{\partial x_{j}}+\frac{\partial \bar{v}_{j}}{\partial x_{i}}\right) \frac{\partial \bar{v}_{i}}{\partial x_{j}}
$$
[7]

Equation for dissipation of turbulent kinetic energy is

$$
\frac{\partial}{\partial x_{j}}\left(\rho \bar{v}_{j} \bar{\varepsilon}\right)=\frac{\partial}{\partial x_{j}}\left[\left(\mu+\frac{\mu_{\mathrm{t}}}{\sigma^{\varepsilon}}\right) \frac{\partial \bar{\varepsilon}}{\partial x_{j}}\right]+C_{1} G \frac{\bar{\varepsilon}}{\bar{k}}-C_{2} \rho \frac{\bar{\varepsilon}^{2}}{\bar{k}}
$$

where $C_{\mu}, C_{1}, C_{2}$ are constants, $\sigma^{k}$ and $\sigma^{\varepsilon}$ are the turbulent Prandtl numbers for $k$ and $\varepsilon$, Tab. 2.

Table 2 The complete model involves a number of coefficients which

\begin{tabular}{|c|c|c|c|c|}
\hline$C_{\mu}$ & $\sigma^{k}$ & $\sigma^{\varepsilon}$ & $C_{1}$ & $C_{2}$ \\
\hline 0,09 & 1,0 & 1,3 & 1,44 & 1,92 \\
\hline
\end{tabular}

\subsection{Spatial discretization and boundary conditions}

The computational grid consisted from 36772482 cells (26 176784 tetrahedra, 10287 pyramids and 10585 411 prisms).

Along the eave framework, the structured grid is generated. The distance from the center point of the walladjacent cell on the eave framework surface was $0,24 \mathrm{~mm}$ corresponding to an averaged non-dimensional wall distance, a $y^{+}$value of 40 over the windward eave framework surfaces, and of 15 over the leeward surface.
Fig. 6 shows the domain of the numerical FSI simulation $(30000 \times 14000 \times 10000 \mathrm{~mm})$.

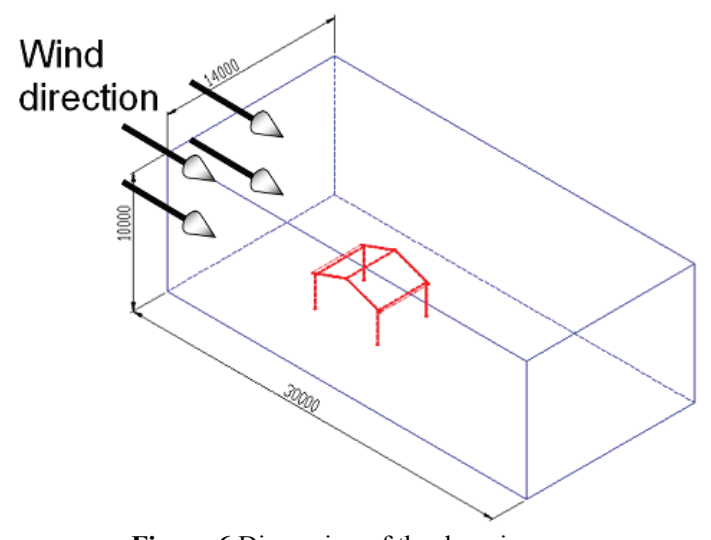

Figure 6 Dimension of the domain, $\mathrm{mm}$

Fig. 7 shows finite volume mesh with some details of structured mesh around the construction. Structured mesh around the geometry is important because it is known that in the boundary layer that occurs when the air flows around a body, there are large gradients of physical quantities, what requires filling of that area with smaller volumes, as opposed to areas away from the body. It should be the best to use as fine geometric mesh to cover the smallest wavelengths and thus small time steps to cover the highest frequencies. On that way, the accuracy of the numerical solution should be very high $[8,9]$.

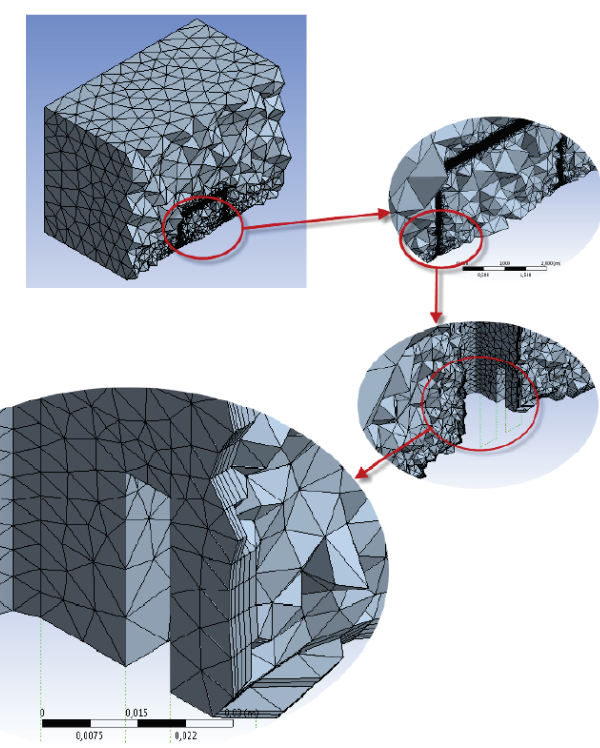

Figure 7 Finite volume mesh

The standard wall functions [10] were applied to the wall boundaries.

The eave framework is set as no slip wall with characteristic of smooth wall. At the inlet of the domain, velocity of $25 \mathrm{~m} / \mathrm{s}$ is set. At the sides and at the top of the domain boundary conditions as free slip walls are imposed. At the outlet of the domain, zero static pressure was imposed. Intensity of turbulence is $5 \%$. 


\section{$5 \quad$ Numerical calculation and results}

The velocity field is shown in Fig. 8 where a stagnation point and changes of velocity vectors directions can be seen.

The flow separation occurs on the places where velocity vectors change direction and air vortex appears. A part of airflow comes back under the eave framework. On the left hand side of the eave framework a new vortex appears which later causes deformations of the eave framework.
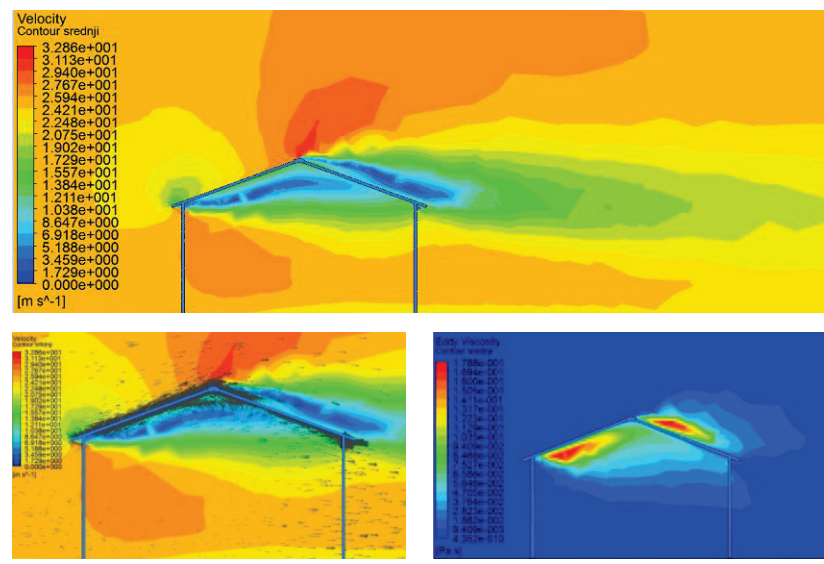

Figure 8 Velocity field, velocity vectors and vortex intensity

The field of vortex intensity is shown in Fig. 8 and can be compared with streamlines shown in Fig. 9. The resulting pressure distribution solution obtained from CFD calculation is set as the boundary conditions on the eave framework when performing the structural analysis.

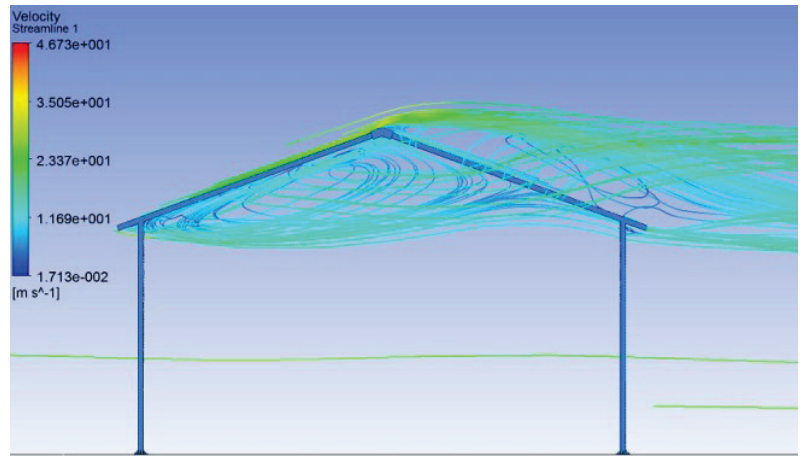

Figure 9 Streamlines

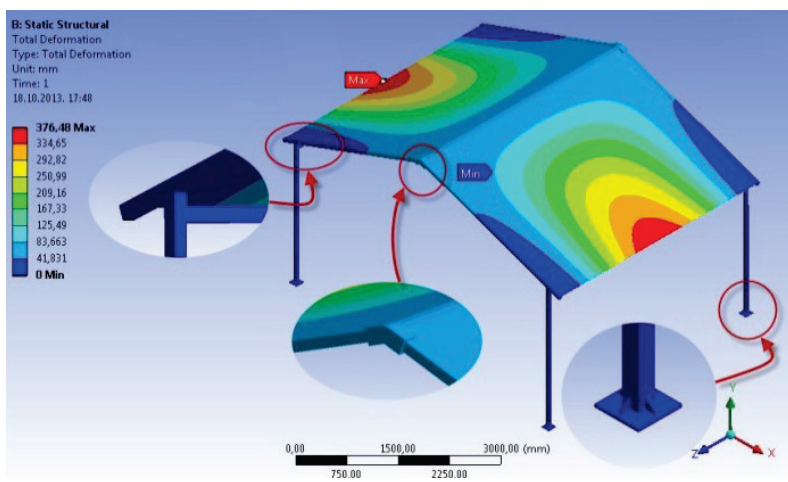

Figure 10 Equivalent deformation distribution, mm

Two separate calculations are performed, the first one is eave framework loaded by self - weight and weight of the snow and the second one is eave framework loaded by the wind blow in most critical direction. It is important to note that the tent should not be stretched while snowing, so in numerical simulation it is stretched only to transfer snow load to the steel construction, so the tent is modeled from steel as well.

Figs. 10 and 11 show deformation and stress distributions. As expected, deformation on the tent is large and that is reasonable, because of small thickness and large area of the tent. There are few local positions of large stress values, but that is negligible because those positions are only local stress concentrations.

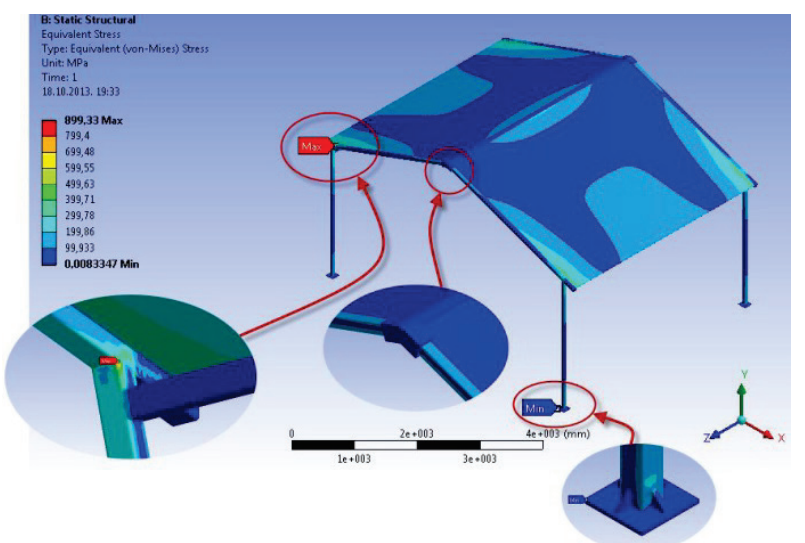

Figure 11 Equivalent stress distribution, $\mathrm{MPa}$

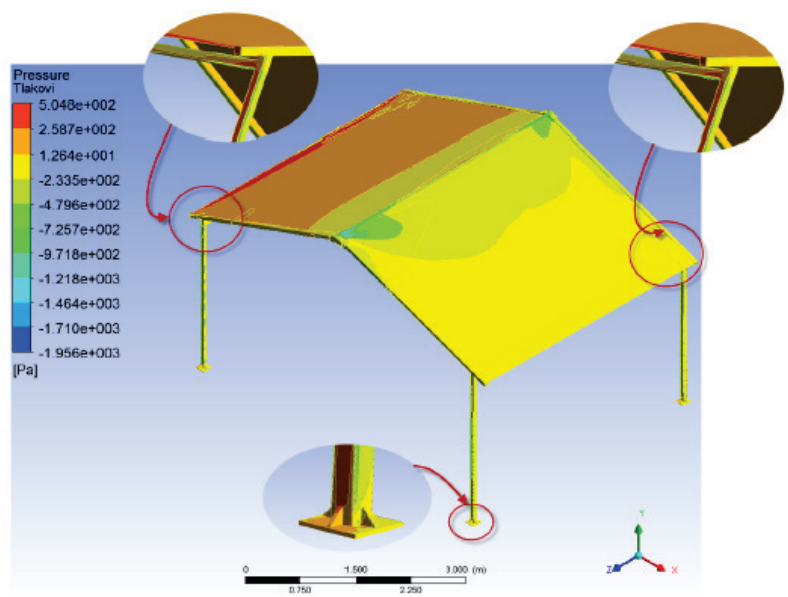

Figure 12 Pressure loading obtained from CFD, $\mathrm{Pa}$

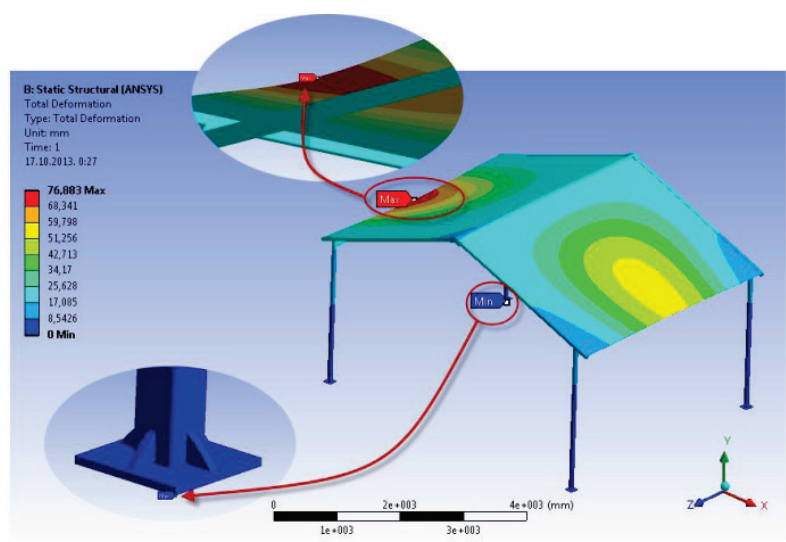

Figure 13 Equivalent deformation distribution, $\mathrm{mm}$

The second case of numerical calculation is FSI. Wind influence is even more important influence to the 
stability of the construction, especially when wind speed is very large.

Figs. 13 and 14 show deformation and stress distributions caused by wind.

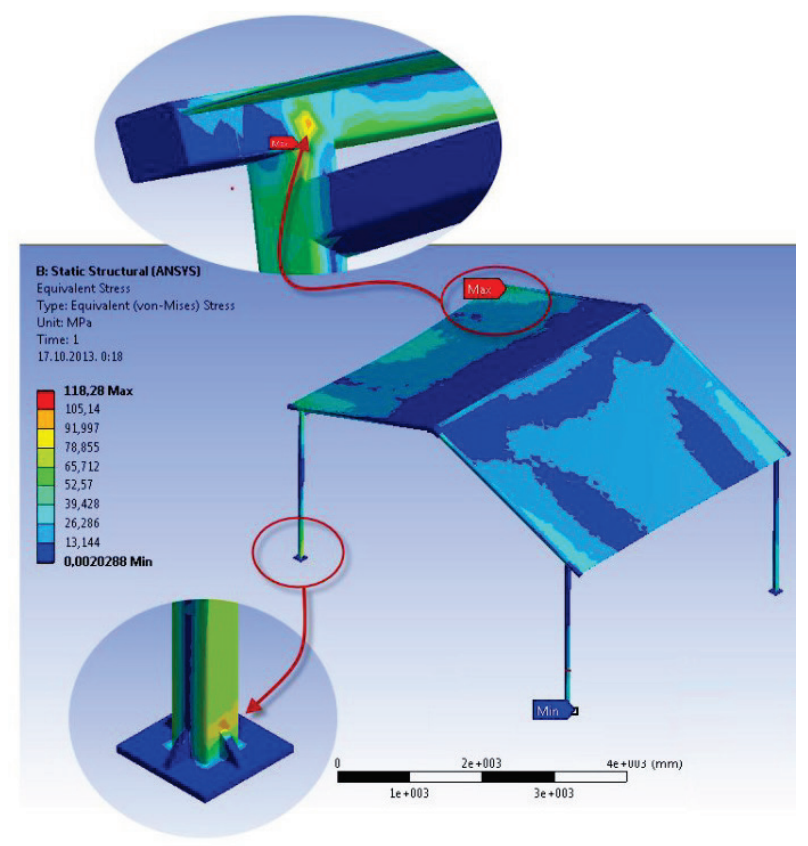

Figure 14 Equivalent stress distribution, $\mathrm{MPa}$

As in earlier case, deformation on the tent is large and that is reasonable, because of the same reasons as in the first case of calculation. There are also few local positions of large stress values, but that is negligible because those positions are only local stress concentrations.

\section{Conclusion}

Eave framework is numerically analyzed in two cases, the first one is eave framework loaded with self weight and weight of snow and the second one is the framework loaded with the wind speed of $25 \mathrm{~m} / \mathrm{s}$. In both cases there are large deformations on the tent, but the tent is not a vital part of the construction, in our cases it is only important to transfer the loading to the construction. So in order to simplify the calculation the tent is modeled from steel.

Regarding stresses, in both cases of the calculations, there is a large amount of the stresses, but those are only the stresses on local small areas and have a local character representing only the stress contractions, which has no influence on the structural stability of construction. It is important to note also that there are some stiffeners in the model (Fig. 1) which additionally contribute to the strength of the framework so it can be concluded that the eave framework satisfies from the standpoint of strength.

\section{References}

[1] Tende\&Pergole, H2 Motiv d.o.o. http://www.tende-pergole.net/palmiye/izvedbe/tilted.html (06.06.2014).

[2] Gan, C. J.; Salim, M. Numerical analysis of Fluid Structure Interaction between wind flow and trees. //
Proceedings of the World Congress on Engineering London, 2014, pp. 1218-1223.

[3] Fu, W.; Yang, M. C.; Zhu, Y. Z.; Lang, L. The wind structure interaction analysis and optimization of parabolic trough collector. // Energy Procedia. 69(2015), pp. 7783.DOI: 10.1016/j.egypro.2015.03.010

[4] Zaninović, K.; Gajić-Čapka, M.; Androić, B.; Džeba, I.; Dujmović, D.Određivanje karakterističnog opterećenja snijegom. // Građevinar. 53, 6(2001), pp. 363-378.

[5] HRN EN 1991-1-4 +NA

[6] ANSYS Release 13, ANSYS Inc., USA

[7] Wendt, J. F.Computational Fluid Dynamics. Springer Verlag Berlin Heidelberg, 2009.

[8] Castillo, J. E. Mathematical aspects of numerical grid generation. Frontiers in Applied Mathematics, Society of Industrial and Applied Mathematics SIAM, Philadelphia, 1991.DOI: 10.1137/1.9781611971019

[9] Peyret, R. Handbook of Computational Fluid Mechanics, Academic Press, 2000.

[10] Launder, B. E.; Spalding, D. B. The numerical computation of turbulent flows. // Computer Methods in Applied Mechanics and Engineering. 3(1974), pp. 269-289. DOI: 10.1016/0045-7825(74)90029-2

\section{Authors' addresses}

Darko Damjanović, dr. sc., mag. ing. mech.

Mechanical Engineering Faculty in Slavonski Brod, Trg Ivane Brlić - Mažuranić 2, 35000 Slavonski Brod, Croatia E-mail: darko.damjanovic@sfsb.hr

Prof. dr. sc. Dražan Kozak

Mechanical Engineering Faculty in Slavonski Brod, Trg Ivane Brlić - Mažuranić 2, 35000 Slavonski Brod, Croatia E-mail: drazan.kozak@sfsb.hr

Mario Holik, mag. ing. mech.

Mechanical Engineering Faculty in Slavonski Brod, Trg Ivane Brlić - Mažuranić 2, 35000 Slavonski Brod, Croatia E-mail: mario.holik@sfsb.hr 